\title{
ELECTION OBSERVATION AND THE QUESTION OF STATE SOVEREIGNTY IN AFRICA
}

\section{Guy Cyrille Tapoko}

Guy Cyrille Tapoko is the Acting Head, Democracy and Electoral Assistance Unit, in the Department of Political Affairs of the African Union, Addis Ababa email: gctapoko@gmail.com

\begin{abstract}
The fundamental question of whether international election observation strengthens or weakens state sovereignty in African states is examined in this article, using a three-branched hypothesis. Firstly, that the presence of international election observers in the host state does not violate state sovereignty. Secondly, that international election observation enhances democratic legitimacy in the state concerned. Thirdly, that with the advent of the right to intervene in international law, international election observation is a tool used to reinforce the legitimate sovereignty of the state. Many researchers argue that international election observation has been used to infringe state sovereignty, especially in post-conflict states. This paper presents a different view by offering a general analysis of the African continent, demonstrating that international election observation makes an invaluable contribution to restoring and reinforcing legitimate state sovereignty.
\end{abstract}

Keywords: election observation, sovereignty, legitimacy

\section{INTRODUCTION}

Election observation in the modern world began in May 1948 when the United Nations led an election observation mission to South Korea to observe the Constituent Assembly election organised in that country. On the African continent, election observation emerged following the democratic wind of change which blew across sub-Saharan Africa after the 1990s. This change was experienced through the organisation of elections reputed to be democratic in countries which had, since their independence, been governed by the single-party system.

The question of whether election observation strengthens or weakens 
state sovereignty is essential to our understanding of the relationship between election observation and the influence it could have on sovereignty. The notion of sovereignty is paramount to this work and deserves to be examined and contextualised in order to properly assess the role election observation can have on any specific type of sovereignty.

Several theories of sovereignty have been advanced, principally the separate but interrelated theories of popular sovereignty (Rousseau 1762) and of national sovereignty (Sieyes 1789). Other theories include internal sovereignty, Westphalian or external sovereignty, and legal international sovereignty. Internal sovereignty refers to the recognised authority of a legitimate government to administer within its territory using its laws and national police. Westphalian or external sovereignty describes the exclusion of external actors from the internal governmental process of a state, a practice that is reciprocal between states. International legal sovereignty confers international recognition on the state when it concludes international treaties with other states (Krasner 2001, p. 233).

According to the theory of popular sovereignty, every citizen is endowed with sovereignty which is translated through universal suffrage and direct democracy. With few exceptions remaining in the world today popular sovereignty, for the sake of convenience, works through elected representatives who hold an imperative mandate. National sovereignty for its part confers sovereignty on the nation, which is an abstract, inalienable and indivisible entity. National sovereignty operates through representative democracy wherein elected deputies work for the interest of the entire nation.

The use of elected representatives by popular and national sovereignties reveals the relationship between the two. This is evident through the inclusion in several state constitutions of the principle that national sovereignty belongs to the people who exercise it through elected representatives (see French Constitution of 1958, Article 3 \& Cameroonian Constitution of 1996, Article 2).

How these representatives are elected is therefore an issue of great importance in the exercise of sovereignty. Ensuring that the right to vote is exercised in a way that procures popular participation in the exercise of national affairs becomes paramount. Having a neutral body watch over the credibility of the process is fundamental to guarantee the proper and legitimate exercise of sovereignty. To this end, election observation missions play an important and neutral role in objectively evaluating electoral processes which constitute the ideal means to select legitimate representatives in a state. Their assessment is done through a mandate to monitor or observe an electoral process. Though used interchangeably, election monitoring is more politically engaged than election observation.

According to the Institute for Democracy and Electoral Assistance (IDEA 1997, p. 10), election observation is: 
... the purposeful gathering of information regarding an electoral process, and the making of informed judgments on the conduct of such a process on the basis of the information collected, by persons who are not inherently authorized to intervene in the process, and whose involvement in the mediation or technical assistance activities should not be such as to jeopardize their main observation responsibilities.

Election observation is considered by IDEA (1997) to be the act of collecting information and expressing a judicious opinion on the basis of the information collected, with reference to precise legislative and regulatory instruments within the framework of the specified electoral process.

Election observation is of invaluable importance to the state holding the election and includes: promoting openness and transparency; enhancing public confidence in the electoral process; secrecy of the vote; easing tensions and increasing security; deterring improper practices and attempts at fraud; identifying and defusing potential areas of conflict; increasing political credibility and legitimacy; and enhancing the credibility of the electoral authority. This explains why election observation is today an almost universally accepted endeavour. However, some countries, like Zimbabwe in 2008, prohibited election observation missions such as those of the European Union from observing elections in their countries.

Election observation is increasingly accepted and even advocated by states which wilfully consent to surrender part of their sovereignty in favour of belonging to international institutions and organisations saddled with the mission to observe elections. This is the case with member states of regional bodies such as the Economic Community of West African states (ECOWAS), the Southern African Development Community (SADC), and continental bodies like the African Union (AU).

Membership of the African Union, for instance, is based on shared values within the AU such as the constitutional change of power. It renders a member state accountable to the $\mathrm{AU}$ for respecting and submitting to this value. The provisions of Articles 4 (p) and 30 of the African Union Constitutive Act clearly state that the AU condemns and rejects any unconstitutional change of government and further emphasises that governments which come to power through unconstitutional means shall not be allowed to participate in the activities of the Union. In line with the above provisions, member states are suspended whenever they contravene a shared value adopted by the AU.

Examples include the suspension of the Republic of Madagascar in 2009 following the political crisis that led to an unconstitutional takeover of power. Madagascar was only readmitted after the country organised credible and 
transparent presidential elections ascertained by the AU Election Observation Mission (AUEOM) to Madagascar in 2013. Guinea Bissau was suspended by the AU after a military coup d'état in April 2012. This country was only readmitted after the 2014 presidential elections were assessed by most election observer missions as being free, credible and transparent. Mauritania was suspended by the African Union in 2005 and again in 2008 because of military coups. It was finally readmitted after the 2014 elections were considered by international election observer missions to have been credible and acceptable (see AUEOM reports on Guinea Bissau \& Mauritania in 2014). International election observation provides a leeway for suspended states to regain their lost membership and improve their international reputation and credit.

Scholars and researchers have approached election observation and state sovereignty from diverse angles. According to Matlosa (2002) election monitoring and observation are, principally, tools to entrench both western hegemony in African states and interference in their internal affairs. Kaiser (1999) opines that the extent to which sovereignty is affected by election observation is determined by the host country's dependence on the donor community; the willingness of donors to exploit this relationship; and the leverage local opposition forces have over the incumbent government regarding an international observer presence and commitment to free and fair elections. By focusing on elections in Nigeria and Madagascar, Kohnert (2004) maintains that election observation is characterised by both diplomatic and technocratic bias to advance the foreign policy of other states and of the international community. Others like Bakary (1992) hold that election observation contributes to the establishment and consolidation of emerging democracies, and to the instauration of peace and the reinforcement of sovereignty.

The available related academic works on election observation and sovereignty have analysed specific case studies on varied themes. This work analyses election observation and sovereignty from a general perspective of the African continent. The methodology used is a direct analysis of some African Union election observation missions and of related researched works on international election observation and state sovereignty.

This work hinges on a threefold hypothesis: the first is to examine whether state sovereignty is violated by the presence of an international election observer mission in a host country with the brief to evaluate and make declarations on the conduct of the electoral process. The next will verify whether the presence of international election observer missions does or does not enhance the democratic process in the country concerned. And finally, whether the advent in current international law of the right to intervene for democratic purposes does make international election observation a tool to promote and reinforce the legitimate sovereignty of the state. 
We begin this work by first examining how the organisation of elections may constitute a challenge to state sovereignty. Secondly we analyse election observation and other related tools used to assess electoral processes. Thirdly, we demonstrate how international election observation enhances the legitimacy of state powers. And finally we explain how, with the advent of the right to intervene for democratic purposes, international election observation represents an invaluable tool for the instauration and fortification of legitimate sovereignty of the state.

\section{BACKGROUND}

International election observation under the OUA/AU began in Namibia in 1989. Initially this practice operated political missions because the observers were selected by member states and deployed under the OAU/AU Mission. After 2006, the AU adopted a technical approach by fielding election observation missions with election experts they recruited through a direct selection process. This was enabled by the adoption of an adequate legal framework that includes: the Constitutive Act of the Union adopted in July 2000; the OAU/AU Declaration on the Principles Governing Democratic Elections in Africa (AHG/Decl.1 XXXVIII) as adopted by the Assembly of Heads of State and Government of the African Union, and the African Union Guidelines for Election Observation and Monitoring Missions, both adopted in July 2002; the African Charter on Democracy, Elections and Governance, adopted on 15 February, 2012; the Universal Declaration of Human Rights (UDHR) adopted by the UN General Assembly in December 1948; the (ICCPR), March 1976; and the International Covenant on Civil and Political Rights Declaration of Principles for International Election Observation and its accompanying Code of Conduct, endorsed by the AU in 2005.

Today the AU practices short- and long-term election observations. Short-term observations concentrate on activities taking place on election day, while longterm election observation is a comprehensive assessment of the entire electoral process. At its $64^{\text {th }}$ Ordinary Session held in Yaounde in July 1996, the OAU was enjoined by member states to step up its involvement in promoting the democratic process on the continent. To this end, the OAU/AU established the Democracy and Electoral Assistance Unit to provide more technical and professional assistance. This unit seeks to provide the AU with credible data to ensure that member states do not violate its shared democratic values.

\section{ELECTIONS: A CHALLENGE TO NATIONAL SOVEREIGNTY}

Elections are fundamental to the security and development of every democratic country and explain why states sacrifice enormous resources for their organisation. 
One of the ways through which a state affirms its sovereignty is to organise and sponsor periodic elections. There may be some challenges to sovereignty when a state lacks the ability to fully fund its electoral process. Therefore, a state's dependence on the donor community to fund elections and the willingness of the donors to exploit the relationship in order to invade state sovereignty may be interesting (Kaiser 1999). Funding could consist of bilateral or multilateral funding, mainly from western countries and international financial institutions.

Elections in a democratic system offer the right to choose representatives of the people directly or indirectly. In monarchies, on the other hand, this right belongs to the monarch, his heirs and appointees. Election 'is the exercise of choice; especially the act of choosing from several possible rights or remedies in a way that precludes the use of other rights or remedies' (Black's Law Dictionary). Elections take place when people have the right to vote, and may vote to make their choices. Consequently, the fate of a country is strongly attached to the choices people make during elections. According to the Department for International Development (2010):

... in peaceful, established democracies, elections represent a crucial opportunity for citizens to select and to hold to account those that seek to govern. At the other end of the spectrum, in countries emerging from conflict, well-timed elections can contribute to conflict resolution and help to consolidate a peace agreement or power-sharing 'deal' between 'elites'.

Elections provide citizens with a real say in who their leaders are, and give them the opportunity to apportion power peacefully. We have general elections during which every eligible voter can exercise his right to vote, and by-elections which concern only designated sections of the electorate. Elections in every country call for the identification of those endowed with popular sovereignty and entitled with the right to exercise universal suffrage. The exercise of popular sovereignty by citizens cannot be seen as a challenge to national sovereignty of the state concerned.

\section{Universal Suffrage and the Question of Popular Sovereignty}

The theory of popular sovereignty endows powers in every citizen within the state to exercise individual sovereignty. Sovereignty belongs to the people who constitute an assembly of the individual citizens of the state. Article 2 of the 1973 French Constitution states that 'sovereignty resided within the people...every portion of the sovereign assembly has right to freely exercise its wish'. 
Suffrage is simply referred to as the right to vote. McCrary $(1897$, p. 2$)$ defines it as:

... a privilege, franchise or trust conferred by the people upon such persons as it deems fittest to represent it in the choice of magistrates or in the performance of political duties which it would be inexpedient or inconvenient for the people to perform in a body. The person upon whom the franchise is conferred is called in an election, an elector or voter. No community extends suffrage to all persons, but places such restrictions upon it as may best serve the ends of government.

Even modern democracies that have adopted the principle of universal suffrage are not much different from McCrary's perspective in 1897. Restrictions continue to exist on the exercise of the right to universal suffrage, the most widespread being the limitation on the age of citizens allowed to vote; for example Nigeria restricts voting to those aged 18 years and more (Nigeria 2010), Cameroon those of 20 years (Cameroon 1996) and Lebanon 21 years (CIA 2009).

Other restrictions include prior forfeiture of rights such as the right to civil liberty, and residence for a minimum duration in the country. In these cases the current implementation of universal suffrage is therefore at variance with the theory of popular sovereignty, which requires all citizens within the state to have equal rights to suffrage irrespective of their rank and social status in the state. The principle applied here is that of 'reasonable restrictions'. Unlike national sovereignty wherein a monarch is seen to incarnate the nation, that is the abstract entity entrusted with sovereignty, popular sovereignty resides within physical individuals and offers no opportunity for the emergence of a monarch. Thus under popular sovereignty, a system of pyramidal control exists between the electorate and their representatives, with the electorate reserving the right of recall at any time should the representatives go counter to their wishes.

\section{The Central Role of the State in the Organisation of Elections}

The organisation of elections is the supreme responsibility of the state. According to the Declaration of Principles for International Election Observation (DoP) (2005, p.1): 'Genuine democratic elections are an expression of sovereignty which belongs to the people of a country, the free expression of whose will provides the basis for the authority and legitimacy of government...'

The state establishes the legal and political framework within which elections will take place, and provides the necessary human and material resources required by election management bodies (EMBs) to organise elections. This is what makes the role of the state central to the holding of elections in every country. Another role of the state is to fund election expenses. Elections continue to be a costly 
exercise especially to developing countries and transition states, and consume significant shares of their national income.

Many African countries, especially post-conflict states, depend on the donor community to fund their elections. These countries usually rely on technical, financial and material support from the donor community to meet their election demands. Examples include the Democratic Republic of Congo (2006 elections) and Sierra Leone (2007 elections) when over $70 \%$ of election funds came from the donor community (Leonard \& Pintso 2008, p. 49).

\section{ELECTION ASSESSMENT: BETWEEN OPINION, JUDGEMENT AND INTERFERENCE}

Election observation seeks to evaluate a given electoral process in order to legitimise it, where appropriate. This is often accompanied by making informed opinions assessing the conduct of the electoral process, based on information gathered by independent and neutral persons who are not inherently authorised to intervene in the process. Some of the principles governing international election observation are: full coverage, impartiality, transparency and professionalism (IDEA 1997 \& EU 2002, pp. 5-6).

Election monitoring is closely related to election observation. According to IDEA (1997), it refers to 'an activity which involves the authority to observe an electoral process and to intervene in the process if relevant laws or standard procedures are being violated or ignored'. Consequently, the mandate of an election assessment mission is determined by whether it is an election observation or an election monitoring mission.

\section{The Mandate of Election Observers}

Though they are different, both election observation and election monitoring have some key issues in common. Their main goals are to evaluate the entire electoral process which covers the pre-election, election and post-election phases. However, an election monitoring mandate is more thoroughgoing and extensive than that of election observation (Matlosa 2002, p. 132).

An election observation mandate is entrusted to a national or international election observation mission to purposefully gather information regarding an electoral process, and to make informed judgements on the conduct of such a process based on the information collected (IDEA 1997). The Commonwealth of Nation's Good Commonwealth Electoral Practice (1997) is one of the first international instruments to bear the semblance of an election observation mandate. It was premised on the 1991 Harare Declaration and provides that: 
... the practice of permitting local and international observers to observe elections helps to inspire confidence in the electoral process and should be encouraged. All observers should operate within the laws of the host country and liaise with the electoral body. Any complaints received by observers from political parties, candidates or individuals should be brought to the attention of the electoral body.

The DoP (2005) defines election observers as having two types of mandate, that is general and specialised mandates. The general mandate evaluates the preelection, election-day and post-election periods in a systematic and comprehensive manner. This is done through the accurate gathering and analysing of information concerning the laws, processes and institutions related to the conduct of elections, including other factors concerning the overall electoral environment. It usually involves long-term observations employing a variety of techniques.

Specialised election observation mandates examine limited pre-election or post-election issues and specific processes (such as delimitation of election districts, voter registration, use of electronic technologies and the functioning of electoral complaint mechanisms). Specialised mandates could be limited in time or scope and such missions must issue clear public statements specifying that their activities and conclusions are limited and do not cover the overall electoral process (ibid.).

Where election monitoring has an interfering mandate, election observation becomes a purposeful fact-finding mission by neutral persons regarding an electoral process wherein the observers are not inherently involved. Rwelamira and Ailola (1994, p. 211) consider election monitoring as:

... [a] little more involved than mere observing. It involves the careful scrutiny and assessment of an election for purposes of determining its impartiality in terms of organisation and administration. It also includes an assessment of the process and actual formulation of the electoral law and the role of the security forces. For this reason, military and police observers are, when appropriate, engaged to monitor the activities of national police and military forces. Other areas which may be monitored are the civil service, the media, political party campaigns, voter education, voter registration and the actual voting as well as the vote counting and announcing processes.

An election monitoring mandate is perceived by some researchers to be interconnected with the technical assistance accorded to an electoral process (Rwelamira \& Ailola 1994, p. 211; Matlosa 2002, p. 135, \& Daniel 1995, p. 95). 
Election observation and monitoring have as their main goals the legitimation, where appropriate, of an electoral process; the enhancement of public confidence; respect for human rights; and the capability of conflict resolution (EU 2000). However, carrying out these different but intertwined mandates often confuses the roles of a classical election observation mission with that of the supervision and certification of electoral processes.

\section{Confusion of the Roles of Observation, Supervision and Certification of Elections}

The interchangeable use of some terms in the domain of elections such as observation, supervision and certification in official documents often breeds confusion (UNSG 1991). The principal reason is that these related practices share a common goal: to determine whether an election was open, free and fair. Differences, however, emerge through the political circumstances surrounding the election, depending on whether we are dealing with non-self-governing, independent or post-conflict countries. Another factor is the origin of the legal framework governing UN involvement: for example, the Trusteeship Council, General Assembly or Security Council; the role of the UN in organising and conducting an election; and the consequences of such involvement (KoenigArchibugi 1997; Stoelting 1992; Théroux-Bénoni 2012). Their main purpose is to determine whether an election was free and fair. But their roles are often different within the context of an electoral process, as we can see below.

\section{Election observation}

Election observation, as described above, is the gathering of information regarding an electoral process. The purpose is to make informed judgments on the conduct of such a process, based on the information collected, by persons who are not inherently authorised to intervene in the process (IDEA 1997). This is not the case with election supervision and election certification.

\section{Election supervision or monitoring}

Election supervision oversees the organisation of the entire component of the electoral process, such as the registration of voters and electoral campaigns. In certain exceptional situations some international election organisations exceed the ordinary role of election observation of supervising and monitoring the electoral process. These organisations exercise the right to intervene in the electoral process whenever the applicable laws and established norms are violated or ignored.

UN Peacekeeping Operations are mandated in some countries to play a direct role in the process and even make judgements on its outcome. Examples include: 
- Direct management and administration of the total electoral process in cases where a state has lost authority, such as in the Somalia United Nations Operation in Somalia (UNOSOM);

- UN technical assistance to South Sudan's referendum in 2011, through the United Nations Mission in Sudan (UNMIS) working alongside the UN Development Programme (UNDP) and the Department of Political Affairs (DPA). They provided major support, including printing and distributing ballots as well as training polling station staff. The mission leadership, and a high-level panel appointed by the UN Secretary-General, supported dialogue between key Sudanese parties in order to prevent conflict and build confidence in the process.

The United Nations also played similar roles in several post-conflict countries, including Timor Leste (2001); Liberia (2005); Democratic Republic of Congo (2006); and Sierra Leone (2007). The supervisory authority's involvement in the process could include offering technical assistance.

\section{Election certification}

Election certification goes beyond gathering information on the conduct of the electoral process, and electoral assistance which offers technical support. It is a recent addition to the United Nations toolbox (Théroux-Bénoni 2012, p. 3). But the African Union has not yet implemented certification of elections in a member state. The UN has used certification in post-conflict environments often dominated by deep mistrust amongst political actors and towards election management bodies, such as in Timor Leste (2007), and Côte d'Ivoire (2010).

As was the case in Côte d'Ivoire, the UN electoral certification intended to attest that the fundamental steps of a post-conflict electoral process adhered to international principles and standards (UNOCI 2009). A certification mandate, moreover, safeguards not only the electoral process, but also the results of the poll (Théroux-Bénoni 2012, p. 3).

Therefore the UN Security Council or the General Assembly may under certain circumstances authorise the Secretary-General to conduct the certification of any given electoral process. In such a case, the Secretary-General is enjoined to certify the credibility of the different aspects of the electoral process organised by the national election management bodies. It does not require the certifying authority to possess clear or perceived neutrality vis-à-vis the electoral process in question. Consequently, candidates may ignore the conclusions of an observation mission, but this is more difficult to do with UN-led certification processes (Théroux-Bénoni, 2012). 
These three terms, observation, supervision and certification may share a common goal and are often used interchangeably. It is however clear that certification and supervision affect state sovereignty by not guaranteeing the complete neutrality of their authorities with regard to the process. Observation, on the other hand, demands a clear and perceived direct exclusion from any acts inherent in the electoral process evaluated by the observers.

Reports on the credibility of an electoral process by international election observation missions are based on the independence and neutrality of the mission towards the entire process. This accounts for the importance the international community attaches to these conclusions and reports which determine policy orientations toward state legitimacy and sovereignty.

\section{ELECTION OBSERVATION: AN ACT TO ENHANCE STATE LEGITIMACY AND REINFORCE STATE SOVEREIGNTY}

The principle established in Article 21 (3) of the Universal Declaration of Human Rights (1948) applies here - 'that the will of the people, as expressed through periodic and genuine elections, shall be the basis of government authority'. Ensuring that the outcome of elections is the genuine expression of the will of the people becomes paramount. This is particularly crucial in situations where there is a deficit of trust between election competitors and the institutions responsible for organising elections.

The presence of a neutral and independent foreign body with a mandate to observe and asses the entire electoral process supports its credibility. This also paves the way for a government recognised as legitimate to emerge from a process that is considered free and fair by international election observation missions.

An international election observation mission is in the interests of both the people in the country organising elections and of the international community. In order for it to effectively and credibly conduct its work, basic conditions must be met. According to the DoP, these conditions include the issuing of an invitation by the country holding elections, and the observance of internationally recognised principles, standards and instruments of democratic elections by the host country (DoP 2005, p. 6).

\section{The Discretionary Right of the State to Invite and Welcome} Election Observers

The discretionary right of a state which intends to organise elections to issue a prior invitation to an international election observation mission serves to affirm 
the sovereignty of the host state. This operates through the principle of prior invitation and the responsibility to welcome election observer missions upon their arrival in the host country.

\section{The principle of a prior invitation}

The condition here is that the country holding elections should 'issue an invitation or otherwise indicate its willingness to accept international election observation missions in accordance with each organisation's requirements sufficiently in advance of elections to allow analysis of all the processes that are important to organising genuine democratic elections' (DoP 2005, p. 4). It is vital to highlight here the relationship which exists between the prior invitation and the notion of state sovereignty. The consideration of a prior invitation is fundamental to demonstrate the discretionary powers of the state with regard to the deployment of an election observation mission on its territory. A state is therefore at liberty not to permit the deployment of any specific election observation mission on its territory (DoP 2005).

This principle of a prior invitation is equally upheld in Articles V (3) and (4) of the Durban Declaration on the Principles Governing Democratic Elections in Africa (AHG/Decl.1 (XXXVIII) of July 2002 and the African Union Guidelines on Election Observation and Monitoring Missions of 2002. Furthermore the African Union adopted this principle in its Charter on Democracy, Elections and Governance of January 2007 in Article 19(1): 'Each State Party shall inform the Commission of scheduled elections and invite it to send an electoral observer mission'.

The respect of the national sovereignty of the host state is an exigency imposed on organisations and institutions engaged in election observation (Laasko 2002, p. 437). In this regard, it is necessary for the election observation missions to wait and receive a letter of invitation from the country intending to organise elections before taking the initiative to deploy observers (Combacau, 1993, pp. 52ff).

\section{The responsibility to welcome election observer missions}

The principle of a prior invitation goes along with that of responsibilities towards the host state. By taking the discretionary decision to invite election observation missions to its territory, the state also commits itself to respect internationally recognised responsibilities that govern the presence of a national or international election observation mission inside its country. International election observation missions fall under the security of the host country. It is the responsibility of the host country and not that of the international election observation mission to guarantee the security of election observers on its territory.

On the African continent, the AU Charter on Democracy, Elections and Governance upholds this responsibility of the host state in Article 19(2) which 
states that: 'Each State Party shall guarantee conditions of security...and full cooperation with the electoral observer mission'.

Subject to the respect of its international engagements, the host state is endowed with the sovereign responsibility to define the rules and conditions to be followed by international election observation missions invited to observe its electoral process. In 2014 Tunisia, for example, required proof of required training by the international election observer before his or her accreditation could be granted. The host state reserves the right to expel from its territory an individual election observer or an international election observation mission that the state considers to have violated these conditions and rules. A case in point is Zimbabwe: in 2000, the government of Zimbabwe banned some international organisations from observing the electoral process, in particular the National Democratic Institute (NDI) which had dismissed the entire electoral process as fraudulent even before it started. Zimbabwe also expelled Pierre Schori, a European Union observer who had entered the country on a tourist visa in February 2002. He made a political statement despite being warned against doing so by the Zimbabwean authorities (Matlosa 2002, pp. 131-134).

Therefore the host state still affirms its sovereignty through its discretion to grant a prior invitation to an international election observation mission; and in the exercise of its responsibility to welcome, secure and define certain rules and conditions to bind election observers on its territory.

\section{The Role of Principles and International Instruments Governing International Election Observation}

The role of principles in international election observation is essentially to ensure that the conduct of the mission safeguards the integrity of the election observation process and the mission as well protecting the sovereignty of the host state. However, the violation of some of these principles and international instruments on election observation has resulted in a negative perception of some international election observation missions, especially by states jealous of their sovereignty. One such example is the heated rivalry between the government of Zimbabwe and western countries during their elections of 2000 and 2002 .

The intergovernmental and international nongovernmental organisations and associations involved in election observation always carry out their work under a defined mandate. This clearly spells out the scope and limitations of their activities upon arrival in the host state. However, in post-conflict settings, there may be some confusion about the role of the principles of election observation.

Key principles that govern election observation include the neutrality of the mission, the deployment of a pre-election assessment mission and respect for the sovereignty of the state, as follows: 


\section{Neutrality of the mission and its approach}

Neutrality is of paramount importance to the mission; firstly, as a fundamental principle, and secondly the actual and perceived independence and neutrality of the mission vis-à-vis the electoral process to be evaluated. This principle seeks to ensure objectivity in the assessment of the process to be carried out by the observers.

In addition, election observation is to be conducted in a rigorous and methodical manner through:

- An evaluation of the electoral process by independent institutions and organisations which differ from those involved in the organisation of the elections. These include the African Union (AU), the Southern African Development Community (SADC), Economic Commission for West African States (ECOWAS), the European Union (EU), the Commonwealth, Organisation internationale de la Francophonie, the National Democratic Institute (NDI), and The Carter Center.

- An objective assessment done by neutral persons and experts of the electoral process in question. In the case of the African Union observers must not be citizens of the country holding elections. Paragraph 6 of the $\operatorname{DoP}(2005$, p. 6) provides that:

... No one should be allowed to be a member of an international election observer mission unless that person is free from any political, economic or other conflicts of interest that will interfere with conducting observations accurately and impartially and / or drawing conclusions about the character of the election process accurately and impartially... International election observation missions should not accept funding or infrastructural support from the government whose elections are being observed as this may raise a significant conflict of interest and undermine confidence in the integrity of the mission's findings ...

- A systematic assessment which takes into consideration respect for the existing system of laws and standards, both national and international, which relate to democracy.

- An objective evaluation which highlights the positive steps made by the host country and suggests recommendations for improvements in future democratic endeavours of the country concerned.

\section{The deployment of a pre-election assessment mission}

Most reputable international election observation missions deploy a pre-election assessment mission ahead of the deployment of election observers, in order to 
evaluate the legal and political framework put in place for the elections. Such a mission seeks to evaluate whether these legal and political frameworks conform with internationally recognised standards for the conduct of democratic elections.

Paragraphs 4.4 and 4.5 of the Guidelines for African Union Election Observation and Monitoring Missions (2002) emphasise the principle of a pre-election assessment mission. These are included in the chapter on the criteria to determine the nature and size of the election observation and monitoring mission to be deployed. The condition of a prior invitation is therefore necessary for the deployment of the pre-election assessment mission. It will produce a report on its findings after evaluating the existing conditions for election organisation.

Should these findings be negative, the African Union will recommend that the country take adequate measures to redress the situation. This was the case with the 2015 elections in Burundi where the AU withheld the deployment of an international election observation mission as certain basic conditions had not been met. In line with Paragraph 11 of the DoP (2005):

A decision by any organization to organize an international election observation mission or to explore the possibility of organizing an observation mission does not imply that the organization necessarily deems the election process in the country holding the elections to be credible. An organization should not send an international election observation mission to a country under the conditions that make it likely that its presence will be interpreted as giving legitimacy to a clearly undemocratic process.

Consequently, the report of a pre-election assessment mission is considered highly important when deciding whether or not to deploy an international election observation mission. This is also affects the nature of the mission to be deployed.

\section{Enhancing respect for the sovereignty of the state}

Every international election observation mission must be conducted with full respect for the sovereignty of the host country. Paragraph 9 of the DoP is very instructive here: it further recommends international election observation missions to respect the human rights of the people in the host country, the laws of the host country as well as its authorities, including electoral bodies, and to act in a manner that respects and promotes human rights and fundamental freedoms.

The role of this principle is also to enhance respect for the sovereignty of the host state by creating necessary conditions for the exercise of state sovereignty, as follows: 
- International election observation encourages the participation of citizens in the host country in electoral processes. The presence of the mission increases the population's confidence with the effect of encouraging more citizens to get involved in the democratic process.

- Election observation by international missions has the potential to prevent electoral violence. In Kenya, post-election violence in 2007 left several hundred dead. The African Union deployed its first ever long-term election observation mission to this country from 12 January to 15 March 2013. The result was a significant reduction of post-election violence in Kenya. The African Union has in general experienced considerable reduction of post-election violence on the continent with the deployment of long term international election observer missions.

- International election observation missions encourage respect for national and international laws and promote the rule of law. The rule of law is a necessary condition for the instauration of democracy in any country. International election observation missions encourage the host county to respect both its self-legislated laws and the international laws which the state has ratified. Contestations, disputes and violence often erupt when laws and rules are violated; this is what international election observation missions aim to avert. A state will be better enabled to exercise sovereignty when it is at peace.

- International election observation promotes the acceptance of election results. The legitimacy of an elected government is reinforced through the acceptance of the election results by the other competitors. Preliminary statements released by international election observation missions, which consider the electoral process to be transparent and credible, will dissuade contestations and persuade the competitors to accept the outcome of the elections; for example, African Union's preliminary statements after the elections in Togo, 2005; Kenya, 2013; Mali, 2013.

- International election observation missions push for the use of established legal means to challenge the disputed outcome of the elections. The call for those taking part in elections to use the judicial means available in the host country, encourages the country concerned to exercise judicial sovereignty over its citizens. This was the case in Nigeria in 2011 when the loser in the presidential elections, Muhammadu Buhari, approached the court to challenge the results of the elections. Another example is Joyce Banda who went to court to challenge the results of the 2014 presidential elections in Malawi. 


\section{Confusion of principles governing international election observation}

This confusion may occur in two ways. The first is when the international election observation mission oversteps its mandate, which is to simply observe the electoral process. The second is when a host state uses the presence of international election observation missions in the country to legitimise an undemocratic process. Experience shows that some international election observation missions have occasionally made declarations which have been considered by the host state to be premature, biased and to have ulterior motives in interfering with the process.

According to Paragraph 12(e) of the DoP, election observation missions are guaranteed the freedom, without interference, to issue public statements and reports concerning their findings and recommendations to improve the electoral process. Public statements are based on accurate and comprehensive observation which notes the positive as well as negative aspects that could have an important impact on the integrity of the electoral process. The findings which constitute the foundation for the public statement must be based on the highest standards of accuracy of information and impartiality of analysis.

However, available evidence has shown instances of alleged confusion of this principle in some public statements from international election observation missions. During the Zambian presidential election of 27 December 2001, the European Union (EU) issued a public statement congratulating Mr. Anderson Mazoka, the presidential candidate of the United Party for National Development (UPND), for supposedly winning the poll even before the vote count had been completed. It turned out that the candidate of the ruling Movement for Multiparty Democracy (MMD), Levy Mwanawasa, had in fact won the presidential election, though by a minority vote of less than $30 \%$. The consequence was that the president-elect had to face a stiff challenge regarding the conduct of the election and the legitimacy of his presidency. Such confusion lends credence to the assertion of diplomatic bias (Kohnert 2004, pp. 83-84) which considers some international election observation missions to be promoting the foreign policies of some western countries.

The other area of confusion over the principle of international election observation is from host countries that exploit the presence of international election observers in the country in order to claim credibility over an undemocratic electoral process.

The experience in many African countries is that, after heavily contested elections, several incumbents may strive to have international election observation missions declare the process as free and fair. Free and fair are the words international donors want to hear in order to accord legitimacy to the victors of the elections (Kaiser 1999). This explains the recent quest by struggling democracies for international election observer presence in their countries during elections.

The term free and fair is defined in the protocol of the European Convention 
on Human Rights as 'free, secret, universal and direct'. Other definitions of the term include the expression of the 'will of the people' or 'a step forward in terms of the country's progress toward democratic governance' (Kaiser, IDEA 1995, p. 14). The vagueness of these definitions and their absence of coherence opens the door for even severely flawed elections to be declared free and fair, to the delight of the victors and the frustration of the losers. A case in point is the highly contested 1995 multiparty elections in Zanzibar, seen by national observers and opposition parties to be poorly organised, whereas many international election observation missions declared them free and fair. The presence of an international election observation mission in this case imbued the electoral process with legitimacy, even though it was marred by controversy right from the start (Kaiser 1999, p. 30).

There are examples where host states successfully negotiated for the presence of international election observers in the country but on a non-invasive election observation mandate. For example, in Algeria in 2014, international election observers were not allowed complete freedom of access. Such a non-invasive mandate does not enable the observers to determine with a high level of certainty whether the electoral process is actually free and fair. Any attempt to engage an invasive election observation mandate is interpreted as interference and an infringement on state sovereignty. The host state's intention is to play to the gallery by exploiting the presence of international election observers in the country as a tool to justify the credibility of the electoral process.

The above acts have incurred huge criticism for international election observation missions, considering that local citizen observers are often not well trained and international observers are expensive to send out. In addition, international observers are frequently accused of not being impartial, of interfering with the election process and thus of creating unnecessary tension.

International law recognises sovereignty as the supreme undivided authority possessed by a state to enact and enforce its law with respect to all persons, property, and events within its borders (Bledsoe \& Boczec 1987, p. 55). Sovereignty offers incumbent governments the international legitimacy to control all facets of governance, including the establishment, amendment, or implementation of laws relating to leadership transitions (Kaiser 1999, p. 31).

A growing phenomenon in Africa is that some incumbents, endowed with such powers, transform themselves into electoral dictators. They maintain their grip on power by always rigging and winning elections after having revised constitutions to include unlimited tenures. In countries where opposition groups have staged stiff resistance, violent contestations have occurred and humanitarian crises have ensued. The result is an increasing reaction, both national and international, to such undemocratic manoeuvres. These powers are today confronted with the inevitable advent of the doctrine of the Responsibility to Protect for democratic purposes. 


\section{THE ADVENT OF THE RIGHT TO INTERVENE FOR DEMOCRATIC PURPOSES}

The principle of the Responsibility to Protect (R2P) for humanitarian purposes was adopted by world leaders in 2005. According to it, the international community has a role to play when sovereign states fail to protect their own populations from genocide, war crimes, ethnic cleansing, and crimes against humanity. The principle makes it a responsibility for the international community to intervene in sovereign states whenever the state is unable or unwilling to handle a humanitarian crisis.

The international recognition of the legitimacy of democracy as the ideal means to acquire and change power dates back to the 1990s in Africa. The doctrine of democratic legitimacy states that democracy is the sole political value to be promoted and that only democratic governments are good. The R2P principle has given a new dimension to this doctrine with the advent of intervention for purposes of promoting democratic legitimacy. According to Reisman (1995) such intervention should be carried out by industrial democracies.

Elections are the major tool used by democracy to reach its goal. Consequently, the credibility of an election is paramount to the determination of democratic legitimacy. In this regard, we observe that the era when the international community remained indifferent towards a country's electoral process is coming to an end. The question of whether or not a country holds elections, postpones them, organises free or flawed elections, or conducts stage-managed or rigged elections is increasingly receding from national sovereignty. The interest of the international community in this domain may be explained by the potential crisis resulting from a flawed electoral process in one country, triggering humanitarian calamities with regional and international effects. Post-election violence in Kenya (2008) and in Ivory Coast (2010) produced humanitarian crises which extended beyond the national borders of both countries. This resulted in the International Criminal Court opening cases for prosecution against the alleged perpetrators of international crimes in both countries.

Though state sovereignty is challenged by the right to intervene, its fundamental objective is to protect, reinforce and strengthen the legitimate sovereignty of the state. This seeks to dissuade electoral dictators from maintaining themselves in power through stage-managed elections.

\section{The Right to Intervene vs Democratic Sovereignty}

The notion of the reserved domain of the state originates directly from international law and is considered in relation to state sovereignty. The dominant 
theory of this notion linked it to what was intimate to the state, interpreted as what belongs to the domestic life of the state. All issues pertaining to the political regime, legislation, award of nationality, etc., belonged to the reserved domain of the state, excluded from external interference.

But with the introduction in international law of the international protection of fundamental human rights, the notion of reserved domain has been seriously eroded (League of Nations 1914). Several international conventions, international custom and even jus cogens have been consecrated on the exclusion of fundamental human rights from the reserved domain of a state's sovereignty. Fundamental human rights are defined as both individual and collective (Article18, Universal Declaration of Human Rights 1948), and as such are protected under the international law.

The establishment of a democratic government through the organisation of genuine elections guarantees the protection of fundamental individual and collective human rights. This justifies efforts made by the international community towards the establishment of a universal democratic order to establish, maintain and consolidate peace which is essential for the protection of fundamental human rights (Kokoroko 2003, p. 8). Michael Reisman (1995, p. 794) affirmed that: 'Popular government is an internationally prescribed human right' and 'Democracy is a right guaranteed by international law'.

In furtherance of this doctrine to promote democratic legitimacy, the international community has intervened in several countries where democracy and genuine elections have been under threat. For example in Sierra Leone, the United Nations Security Council intervened for the first time in Africa in 1998, using coercive measures to oust the military junta. This paved the way for democratic elections to be organised (Acheampong 1998, p. 98).

The African Union has been very critical towards the undemocratic or unconstitutional acquisition of power. The AU has recently taken many actions to intervene in countries where the rules of democracy have been violated. For example the AU intervened in Togo in February 2005 to reverse the unconstitutional handing of power to Faure Gnassingbé through parliamentary designation, following the death of his father Gnassingbé Eyadema. Togo was constrained to organise presidential elections in May 2005, enabling Faure Gnassingbé to take power through constitutional means.

With the advent of the right to intervene for democratic purposes, state sovereignty is further influenced by the foreign policy orientation of many western states, particularly America and the European Union. These states include the promotion of democratic legitimacy in other states as national and regional foreign policy. This policy is illustrated in the European Union's inclusion of democratic conditionality in the EU/ACP Convention of 23 June 2000 in Cotonou (Benin), which included developmental aid (Feuer 2000, p. 106) . 
State sovereignty in Africa is increasingly influenced by the AU's consideration of adopting a policy in the future to deploy international election observation missions to member states holding elections, even without prior invitations from the states concerned. This deviation from the principle of a prior invitation before the deployment of an international election observation mission, seeks to promote democratic legitimacy. This is especially in states where governments have turned into dictatorships by organising elections and rigging a win.

\section{Intervention to Restore and Reinforce the Legitimate Sovereignty of the State and its Institutions}

The presence of international election observation missions and their assessment of the electoral process is an invaluable way to ascertain the credibility of the elections. This is the principal tool used to judge how power is acquired in a state. The will of the people expressed in the required conditions is the legitimate source of power in a state, hence the legitimate foundation of sovereignty.

Intervention to restore democratic legitimacy becomes necessary when political and military authorities unjustly exploit the notion of state sovereignty in order to abuse the legitimate will of their people. This will enable sovereignty to be handled by those rightly entrusted with legitimate power in the state. In order for this to be effective, it is important that the electoral process be evaluated by neutral international election observation missions which are not inherently involved in the process.

The international community had to rely on the findings of international election observation missions to restore legitimate sovereignty in Angola in the year 2000. International election observation missions had confirmed the verdict of the 2000 elections in Angola but UNITA (União Nacional para a Independência Total de Angola) refused to respect this verdict. The international community imposed a total isolation of the rebel movement and used this non-coercive measure to compel UNITA to respect the results of free and democratic elections (Thomé 2000, pp. 143-167). Through the assessment of the electoral process by international election observation missions, the international community was able to intervene and restore legitimate sovereignty to a democratic state.

The African Union condemned attempts by the incumbent president of the Gambia to withhold power after losing the election in 2016, and supported the ECOWAS intervention to restore democratic legitimacy in this country. Through suspension, coercive measures and intervention, African states were constrained to run organised elections evaluated by international election observation missions as being credible. This enabled them rejoin or stay in this continental 
body. Legitimate power acquired through genuine and credible elections should be the foundation of sovereignty in African Union member states.

\section{CONCLUSION}

Far from limiting or eroding state sovereignty, international election observation should be perceived as a tool to confer either legitimacy or illegitimacy on an electoral process. This condition is a sine qua non for determining the democratic regime entrusted with sovereign powers in a state.

According to the $\operatorname{DoP}(2005$, p. 1):

Genuine democratic elections are an expression of sovereignty, which belongs to the people of a country, the free expression of whose will provides the basis for the authority and legitimacy of government. The rights of citizens to vote and be elected at periodic, genuine democratic elections are internationally recognized human rights.

Flawed elections have served as drivers of violence and humanitarian catastrophes in Africa. The enfeebled nature of African states increases their vulnerability and the consequences of crisis here are often devastating, illustrated by the recent examples of Kenya (2007) and Ivory Coast (2010).

International election observation missions undertake their fact-finding tasks on elections in line with the constitutional provisions and electoral laws of individual countries, and within the broader framework provided by international and regional democratic and human rights instruments. Intervention for democratic purposes is necessary when the people are victimised under military or civilian dictators to whom free and democratic elections is merely a phrase. When the system of election consists of electoral holdup, intervention for democratic purposes becomes necessary.

International election observation may pave the way for intervention to reinforce the legitimate authority of elected officials in a state. The democratic legitimacy of power increases the moral authority of the state in the exercise of full sovereignty. But the quest for democratic legitimacy should not serve as a pretext for unilateral intervention by more powerful states in weaker countries. It should not become an excuse for the strong to impose arbitrary interventionist policies over the feeble. The right to intervene should not be subject to abusive and disproportionate qualifications that may promote the hegemony of powerful states in the west (Salmon 2002, p. 191).

In order to achieve their goal of objectively evaluating electoral processes, international election observation missions must scrupulously adhere to 
internationally recognized principles and standards. Only in this way will international election observation restore and reinforce the legitimate sovereignty of states.

\section{- REFERENCES}

Acheampong, K 1998, 'Africa and the Vicissitudes of the Human Rights Principle of the Will of the People as the Basis of the Authority of Government', Lesotho Law Journal, vol. 1, no.1 pp. 87-115.

African Union 2007, African Charter on Democracy, Elections and Governance, African Union, Addis Ababa, Ethiopia.

African Union 2002, African Union Guidelines on Election Observation and Monitoring Mission, African Union, Banjul, The Gambia.

African Union 2002, OAU/AU Declaration on the Principles Governing Democratic Elections in Africa, AHG/Decl.1 (XXXVIII), Durban, South Africa.

African Union 2013, Reports of African Union Election Observation Missions for Madagascar and Kenya viewed 15 September 2014. Available at < http:// www.au.int>

Arnaud AJ \& Belley JG 1988, Dictionnaire encyclopédique de théorie et de sociologie $d u$ droit, Librairie générale de droit et de jurisprudence/E-Story-Scientia, Paris/Bruxelles.

Bakary, TD 1992, La démocratie par le haut en Côte d'Ivoire, l'Harmattan, Paris.

Bledsoe RL, Boczek B 1987, The international law dictionary, Clio Press Ltd., Oxford. Brownlie, I 1990 Principles of public international law, 4th ed. Oxford University Press, Oxford.

Cameroon 1996, Constitution of the Republic of Cameroon, Article 2 as amended, National Gazette, Yaounde.

Central Intelligence Agency 2009, The World Factbook, Washington, DC, viewed 21st December, 2015, < https://www.cia.gov/library/publications/theworld-factbook/index.htm

Combacau, J 1993, 'Pas une puissance, une liberté: la souveraineté internationale de l'État', Pouvoirs, vol. 67 , no. 47 pp. 47-58.

Commonwealth Secretariat 1997, Good Commonwealth Electoral Practice: a working document, Commonwealth Secretariat, London.

Department for International Development 2010, Electoral Assistance and Politics: Lessons for International Support, London.

Dupuy, PM 1987, 'Situation et fonctions des normes internationales', in M Bettati \& B Kouchner (ed), Le devoir d'ingérence, Denoël, Paris.

Feuer, G 2002, 'Le nouveau paradigme pour les relations entre l'UE et les États ACP : l'accord de Cotonou du 23 juin 2000', Revue générale de droit international public, vol. 106, n. 2, pp. 269-293. 
France 1958, Constitution de la République Française, Journal Officiel, Paris. Garner, B 2004, Black's Law Dictionary, $9^{\text {th }}$ ed, Dallas.

International Institute for Democracy and Electoral Assistance, 1997, Code of Conduct for Ethical and Professional Observation of Elections, Stockholm, viewed 16 September $2014<$ http: / / www.idea.int>

Kaiser, PJ 1999, 'Power, Sovereignty and International Election Observers: The case of Zanzibar', Africa Today, vol. 46, no. 1, pp. 29-46.

Koenig-Archibugi, Mathias 1997, 'International Electoral Assistance', Peace Review, vol. 9, no. 3, pp 357-364.

Kohnert, D 2004, 'Election Observation in Nigeria and Madagascar: Diplomatic Vs Technocratic bias', Review of African Political Studies, vol. 31, no. 99, pp. 83-101.

Kokoroko D 2003, 'Souveraineté étatique et principe de légitimité démocratique', in Revue Québécoise de Droit International, pp 37-59.

Laasko, L 2002, "The Politics of International Election Observation: the Case of Zimbabwe in 2000', Journal of Modern African Studies, vol. 40, no. 3, pp. 437464.

Théroux-Bénoni, L-A 2012, Lessons for UN electoral certification from the 2010 disputed presidential poll in Côte d'ivoire, Centre for International Governance Innovation, Waterloo, Ont.

McCrary GW 1897, A Treatise on the American Law of Elections, 4th ed., Callaghan \& Co, Chicago.

Matlosa, K 2002, 'Election monitoring and observation in Zimbabwe: hegemony versus sovereignty', African Journal of Political Science / Revue Africaine de Science Politique, vol. 7, no. 1, pp. 129-154.

Nigeria 2010, Electoral (amendment) Act, Section 12, National Assembly, Nigeria.

Reisman, M 1995, 'Humanitarian Intervention and Fledgling Democracies', Fordham international law journal, vol. 18, no. 3, pp. 794-805.

Rousseau, JJ 1762, Du Contrat Social ou Principes du droit politique, Amsterdam, Marc-Michel Rey.

Rwelamira, M. and D. Ailola 1994, 'International Monitoring of Free and Fair Elections' in N. Steytler, J. Murphy, P. de Vos and M. Rwelamira (eds.) Free and Fair Elections, Juta and Co. Ltd., Kenwyn.

Salmon, J 2002, 'Démocratisation et souveraineté : l'impossible conciliation?', in R Mehdi, (ed), La Contribution des Nations Unies à la démocratisation de l'État. Dixièmes Rencontres internationales d'Aix-en-Provence, Colloque des 14 et 15 décembre 2001, Pedone, Paris, pp. 191-200.

Sieyes, EJ 1789, What is the Third Estate, (n.p.), Paris.

Stoelting, David 1992, 'The Challenge of UN-Monitored Elections in Independent Nations', Stanford Journal of International Law, vol 28, pp. 371-424. 
Théroux-Bénoni, L-A 2012, Lessons for UN electoral certification from the 2010 disputed presidential poll in Côte d'ivoire, Centre for International Governance Innovation, Waterloo, Ont.

Thomé, N 2000, 'L'Angola, les Nations Unies et les sanctions : quelle efficacité ?' in Recontres Internationales d'Aix-en-Provence \& R Mehdi (ed), Les Nations Unies et les sanctions. Quelle efficacité ? Colloque des 10 et 11 décembre 1999, Pedone, Paris.

Trotha, TV 1993, 'C'est la pagaille: Quelques remarques sur l'élection présidentielle et son observation internationale au Togo, 1993', Politique africaine no. 52 pp. 152-159.

United Nations Organisation 2005, Declaration of principles for international election observation, New York. 